\title{
Endoscopic management of pancreatic pseudocysts
}

\author{
Shyam Varadarajulu
}

Department of Medicine, Basil I. Hirschowitz Endoscopic Center of Excellence, University of Alabama Birmingham

\begin{abstract}
The conventional management of pancreatic pseudocysts involves surgery or percutaneous drainage. While surgery is associated with significant complications and mortality, percutaneous drainage is associated with prolonged hospitalization and often times the need for other adjunctive treatment measures. Therefore, the use of endoscopy to drain these pseudocysts is becoming increasingly popular. In this review, we will be examining the techniques, outcomes and costs associated with the endoscopic drainage of pancreatic pseudocysts.

Key words Acute fluid collections, endoscopic ultrasound, pancreatic pseudocyst
\end{abstract}

\section{Introduction}

Peripancreatic fluid collections encompass a group of fluid reservoirs located within the abdominal cavity and result from disease processes that can damage the pancreatic ducts. Therefore, they are often seen as complications of acute and chronic pancreatitis, but can also occur secondary to trauma, surgery and malignancy. ${ }^{[1,3]}$ The different types of peripancreatic fluid collections that can exist as determined by the Atlanta Classification are listed below. ${ }^{[1,2,4]}$

- Acute fluid collection is free pancreatic fluid that has accumulated around the pancreas and is not encased within a wall. It forms rapidly within 48 hours following acute pancreatitis and may evolve into a pseudocyst, an abscess, or resolve.

- Pancreatic pseudocyst is a collection of non-infected pancreatic fluid that is surrounded by granulation or fibrous tissue that is lacking in epithelium. It can be classified as either acute or chronic depending on whether it forms after acute or chronic pancreatitis.

- Pancreatic abscess is similar in appearance to pseudocysts but is composed of infected pancreatic fluid. It can be

\begin{tabular}{|l|c|}
\hline \multicolumn{2}{|c|}{ Access this article online } \\
\hline \multirow{2}{*}{$\begin{array}{l}\text { Website: } \\
\text { www.jdeonline.in }\end{array}$} & Quick Response Code \\
\hline DOI: & \\
10.4103/0976-5042.95035 & \\
\hline
\end{tabular}

distinguished from pancreatic necrosis as it typically lacks necrotic pancreatic tissue.

- Pancreatic necrosis results from the destruction of pancreatic tissue. In the early stages of its formation, it consists of non-viable pancreatic tissue, but later on can be surrounded by a wall to form a distinct structure.

The drainage of these peripancreatic fluid collections is important because they can be associated with significant morbidity and mortality. For instance, in addition to abdominal pain and sepsis, they can compress the stomach and biliary tree, resulting in vomiting and jaundice. ${ }^{[5,6]}$ Furthermore, larger pancreatic pseudocysts can rupture and produce ascites and pleural effusions. ${ }^{[6]}$ Therefore, the main aims of peripancreatic fluid drainage are to achieve satisfactory resolution of the fluid collection and to provide symptomatic relief.

The conventional methods for managing peripancreatic fluid collections have been to perform either surgical or percutaneous drainage ${ }^{[6]}$ Unfortunately, both of these methods are associated with significant complications. Therefore, since its first use in the late 1980s, endoscopic drainage has been gaining popularity as an alternative to surgery and percutaneous drainage, especially in combination with endoscopic ultrasound (EUS). In this review, we will be examining the endoscopic management of peripancreatic fluid collections.

\section{Acute fluid collections}

Acute fluid collections are free fluid collections located within the abdominal cavity and drainage is usually not necessary as they can resolve spontaneously without 
treatment. However, if they become symptomatic or infected, drainage is indicated. In this case, transpapillary drainage in which a stent is inserted through the pancreatic duct to bridge the duct leakage can be successful ${ }^{[4,7]}$ [Figures $\left.1 \mathrm{a}, \mathrm{b}\right]$. In one study, the overall clinical success rate following transpapillary stent insertion was $55 \%$, with the bridging stent resulting in successful resolution of the fluid collection in $92 \%$ of cases, compared to just $6 \%$ for stents placed across the ampulla and $2 \%$ for those inserted into the damaged duct. ${ }^{[8]}$ This is corroborated by another study, which showed that the insertion of transpapillary stent resolved peripancreatic fluid collections in $58 \%$ of patients, with the highest success rates observed with bridging stents (48\%) compared to stents inserted just across the papilla (28\%) or into the damaged duct itself (24\%). ${ }^{[9]}$ The outcome of transpapillary pancreatic duct stenting for the management of acute fluid collections is shown in Table 1.

\section{Pancreatic pseudocysts and abscesses Technique}

The endoscopic management of pancreatic pseudocysts and abscesses are very similar. They involve accessing the fluid collections through the wall of the stomach or the duodenum, and in recent years the concurrent use of endoscopic ultrasound (EUS) to facilitate access has become popular. The

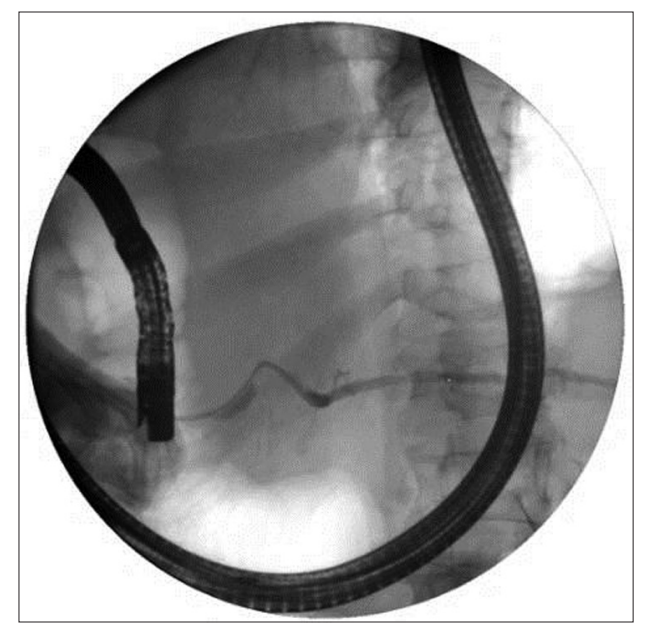

Figure 1a: Pancreatogram revealing a leak from the main pancreatic duct in a patient with acute pancreatic fluid collection methodology of transmural endoscopic peripancreatic fluid drainage is outlined below:

\section{Non- EUS guided transmural drainage}

Without the employment of EUS, the endoscopic drainage of peripancreatic fluid collections is a rather "blind" procedure. It involves a search for a luminal compression in the stomach and the duodenum using a double-channel gastroscope or a duodenoscope. If a luminal compression is identified, the gastric or duodenal wall is punctured by using a needle-knife catheter to create a cyst-enterostomy fistula. After access to the pseudocyst, a 0.035 -inch guidewire is coiled within the pseudocyst and dilatation of the fistula is performed using an 8-15 mm biliary balloon dilator under fluoroscopic guidance. After dilatation, multiple 7 or $10 \mathrm{~F}$ double-pigtail endoprostheses are placed [Figures $2 \mathrm{a}-\mathrm{c}$ ] and a sample of the aspirate is sent for Gram stain and culture.

\section{EUS-guided drainage}

This is performed using a 19-gauge needle, which is introduced into the pseudocyst via a therapeutic linear array echoendoscope. Before puncture, the cyst morphology is evaluated by EUS and color Doppler ultrasound is used to identify regional vessels. A 0.035 -inch guidewire is then introduced through the needle and coiled within the pseudocyst

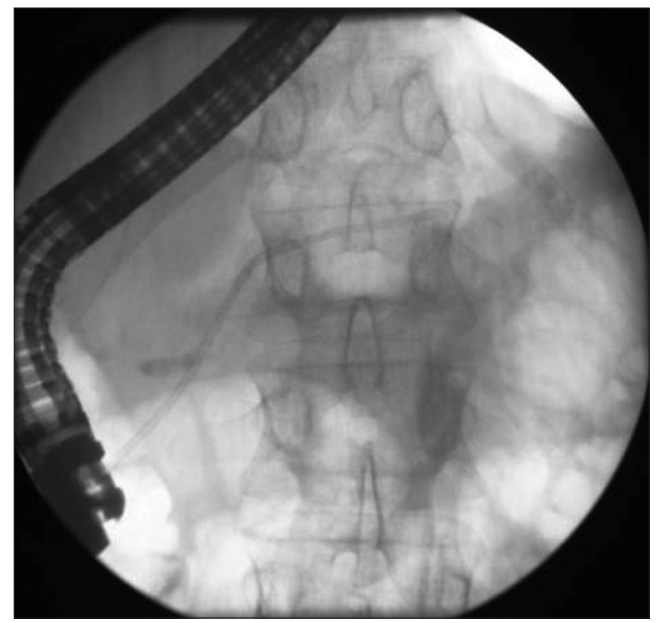

Figure 1b: At ERCP, the leak is managed by placement of a bridging stent

\begin{tabular}{|c|c|c|c|c|}
\hline Authors & No. of patients & Technical success $n(\%)$ & Clinical success $n(\%)$ & Complications $\boldsymbol{n}(\%)$ \\
\hline \multirow[t]{4}{*}{ Varadarajulu et al. (2005) ${ }^{[8]}$} & 97 & $92(95)$ & Overall: 52 (55) & $6(7.1)$ \\
\hline & & & Across ampulla: 3 (6) & \\
\hline & & & Into damaged PD: 1 (2) & \\
\hline & & & Bridging stent: 48 (92) & \\
\hline \multirow[t]{4}{*}{ Telford et al. $(2002)^{[9]}$} & 43 & $43(100)$ & Overall: 25 (58) & $4(9)$ \\
\hline & & & Across papilla: 7 (28) & \\
\hline & & & Into damaged PD: 6 (24) & \\
\hline & & & Bridging stent: 12 (48) & \\
\hline
\end{tabular}

PD: Pancreatic duct 


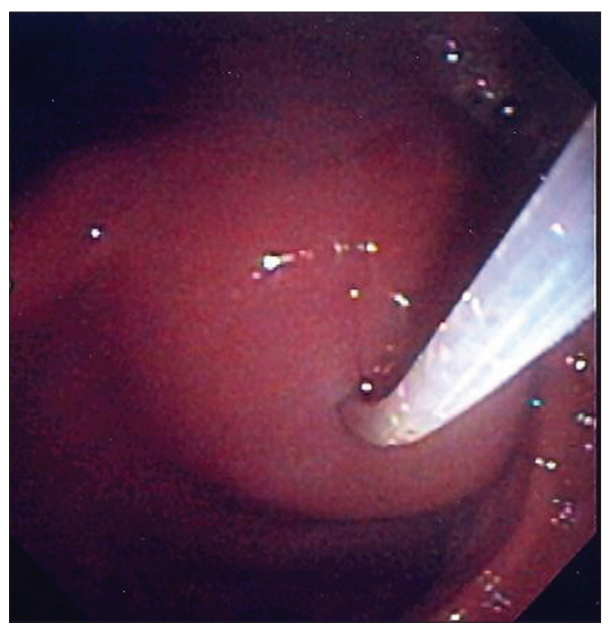

Figure 2a: Peripancreatic fluid collection causing a luminal compression at the gastric antrum is accessed using a needle-knife catheter at non-EUS guided drainage

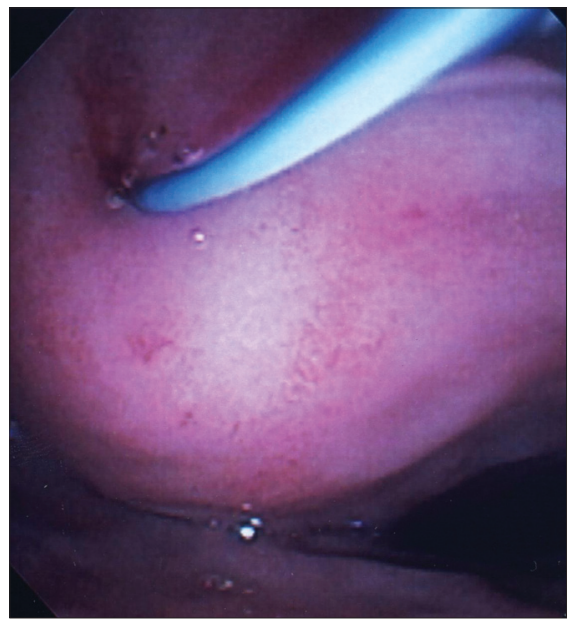

Figure 2b: The needle knife catheter is exchanged for a 0.035 inch guide wire that is coiled within the fluid collection

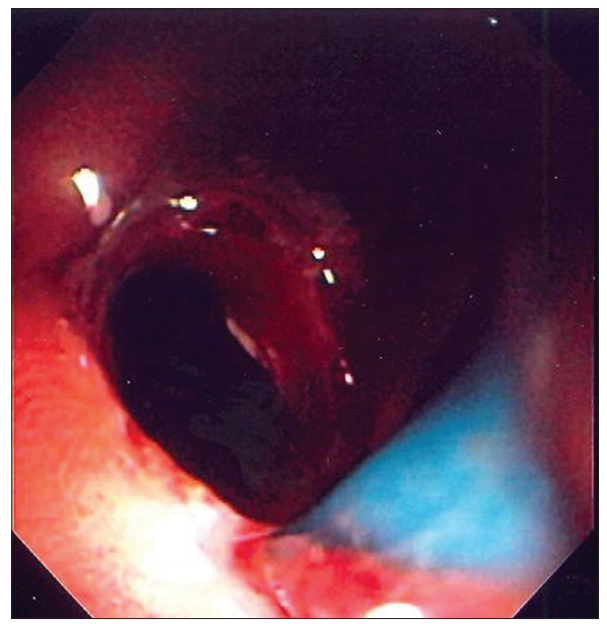

Figure 2c: Wide opening seen after dilation of the cyst-enterostomy tract using an $8 \mathrm{~mm}$ through-the-scope biliary balloon dilator

under fluoroscopic guidance. The tract is sequentially dilated by first passing a $4.5 \mathrm{~F}$ ERCP cannula and an $8-15 \mathrm{~mm}$ biliary balloon dilator [Figures 3a-d]. If the wall of the peripancreatic fluid collection is very thick and precludes dilation with an ERCP cannula, a needle-knife catheter can be passed over the guidewire to puncture the wall and facilitate access. After dilatation, multiple 7 or $10 \mathrm{~F}$ double-pigtail endoprostheses are placed and a sample of the aspirate is sent for analysis.

In patients with pancreatic abscesses, a $10 \mathrm{~F}$ nasocystic catheter is placed in addition to the stents to facilitate periodic flushing and aspiration with normal saline every 4 hours.

\section{Technical and clinical outcomes}

\section{Non-EUS guided transmural drainage}

High rates of technical and clinical successes have been reported with non-EUS guided endoscopic drainage of pseudocysts and abscesses. Studies have reported technical success rates of $71-100 \%$ and clinical success rates of $62-97 \% .^{[6,10-15]}$ The complication rates in patients undergoing non-EUS guided drainage of pseudocysts ranged from $10-34 \%$. The most common complications seen were hemorrhage and perforation. ${ }^{[6,10-15]}$ A summary of these studies is shown in Table 2.

\section{EUS-guided drainage}

Several observational studies have been carried out to investigate the efficacy of EUS-guided drainage of pseudocysts and abscesses. They all resulted in high technical and clinical success rates, ranging from $89-100 \%$ and $82-100 \%$ respectively. ${ }^{[3,16-20]}$ Complication rates were between 1.7 and 15\% following EUS-guided drainage and included bleeding, perforation, pneumoperitoneum, sepsis and problems with the stents such as obstruction and migration. ${ }^{[3,16-20]}$ Recurrence rates were also low and ranged from $3-17.7 \% \cdot{ }^{[3,16-20]}$ A summary of these studies is shown in Table 3.

\section{Non-EUS versus EUS-guided drainage}

Two randomized trials have compared EUS-guided and non-EUS guided drainage of pseudocysts. In one study, 30 patients with pseudocysts were randomized into EUS-guided and non-EUS guided groups. ${ }^{[21]}$ While the technical success was $100 \%$ with EUS, it was only $33 \%$ with the non-EUS based approach. In fact, patients receiving EUS-guided drainage were 39 times more likely to have successful drainage compare to individuals undergoing the non-EUS procedure. However, there was no statistical difference in the rates of clinical treatment success $(100 \%$ vs $87 \%$ ) or complications ( $0 \%$ vs $13 \%$ ) between the EUS and non-EUS drainage groups. ${ }^{[21]}$

These results are supported by the second randomized trial, which also showed statistically significant higher technical success rates in the EUS compared to the non-EUS group (94\% vs $72 \%) \cdot{ }^{[22]}$ Clinical success rates were similar in the two groups with rates of $97 \%$ in the EUS and $91 \%$ in the non-EUS group. Additionally, complication rates were similar between the two groups ( $7 \%$ in EUS, $10 \%$ in non-EUS drainage). 


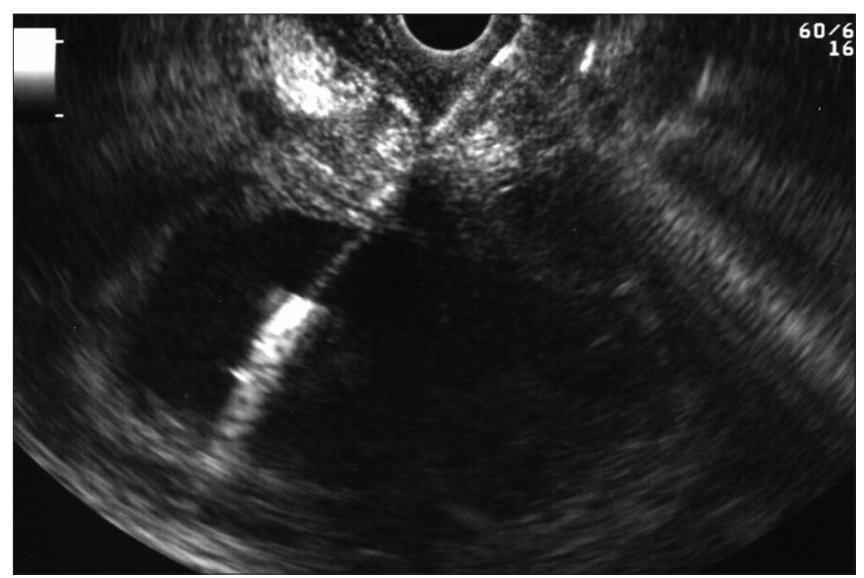

Figure 3a: Peripancreatic fluid collection accessed under EUS-guidance using a 19-gauge FNA needle

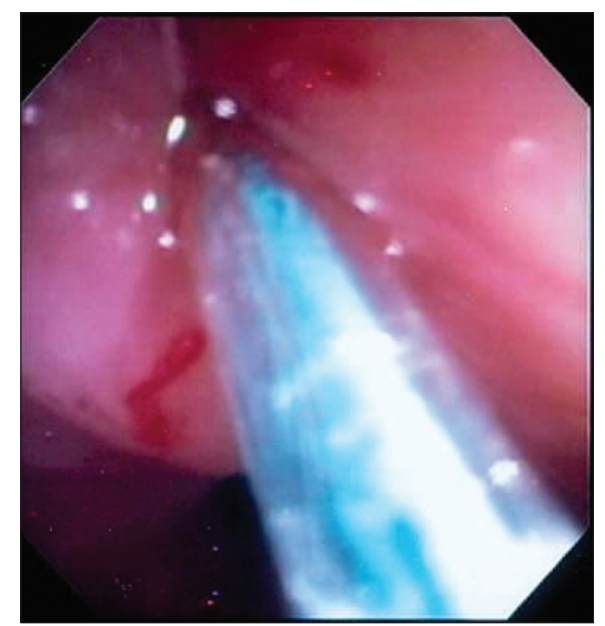

Figure 3c: Further dilation of the cystenterostomy tract being performed using an $8 \mathrm{~mm}$ biliary balloon dilator

Therefore, EUS-guided method of pseudocyst drainage appears to be associated with higher technical success rates and this is due to several reasons.

Firstly, EUS allows the endoscopist to view in real-time the exact location of the fluid collection and hence it can be drained in the absence of luminal compression. ${ }^{[5]}$ This is particularly useful as significant luminal compression can be absent in patients with edema of the gastric wall from hypoalbuminemia and those with peripancreatic fluid collections that are either too small or located at the pancreatic tail. ${ }^{[23]}$ Additionally, the gallbladder and spleen can also cause luminal compression and hence may be mistaken for pseudocysts without EUS. ${ }^{[23]}$ In one study, all patients who had peripancreatic fluid collections at the pancreatic tail initially failed endoscopic drainage without EUS, but were able to undergo successful drainage afterwards with the aid of EUS [Figure 4].

Secondly, the use of color Doppler ultrasound with EUS makes it possible to examine the location of blood vessels within the wall of the stomach and the duodenum. Therefore, this allows transmural drainage of pancreatic fluid collections to occur

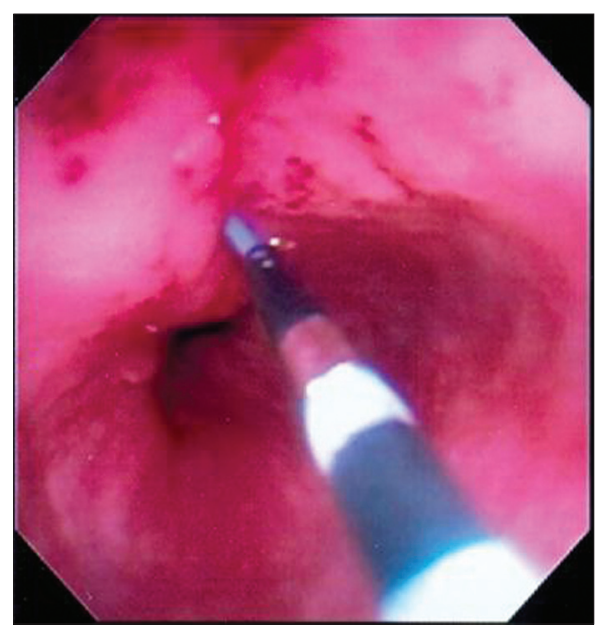

Figure $3 \mathrm{~b}$ : After passage of a 0.035 inch guide wire, the cystenterostomy tract is dilated using a 4.5Fr ERCP cannula

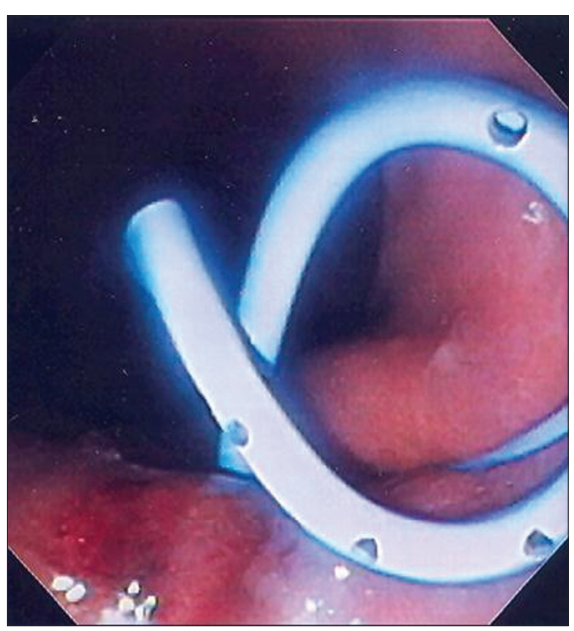

Figure 3d: Deployment of a 10-Fr double pig-tail plastic stent into the peripancreatic fluid collection

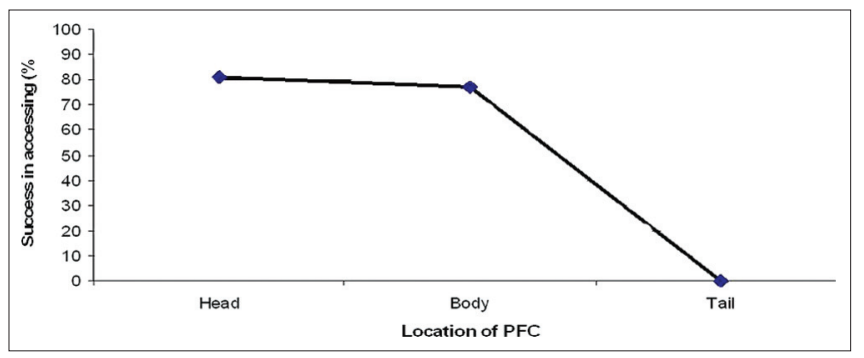

Figure 4: Peripancreatic fluid collections located at the tail region of the pancreas are more likely to fail drainage by the non-EUS approach. (Adapted from reference 24)

more safely by minimizing the risk of hemorrhage, especially in patients with portal hypertension.

Lastly, the use of EUS allows the nature, size and number of peripancreatic fluid collections to be examined more closely prior to drainage. Thus it is invaluable for discriminating between the different types of peripancreatic fluid collections, and between benign and malignant cystic lesions of the 


\begin{tabular}{|c|c|c|c|c|c|c|c|c|}
\hline Authors & Type of PFC & $\begin{array}{r}\text { Type of } \\
\text { drainage }\end{array}$ & $\begin{array}{c}\text { No. of } \\
\text { patients }\end{array}$ & $\begin{array}{c}\text { Technical } \\
\text { success } n(\%)\end{array}$ & $\begin{array}{c}\text { Clinical } \\
\text { success } n(\%)\end{array}$ & $\begin{array}{c}\text { Recurrence } \\
n(\%)\end{array}$ & $\begin{array}{c}\text { Hospital } \\
\text { stay (days) }\end{array}$ & $\begin{array}{c}\text { Complications } \\
n(\%)\end{array}$ \\
\hline \multirow[t]{4}{*}{ Baron et al. (2002) $)^{[10]}$} & Total & TM & 138 & NR & $113(82)$ & $18(16)$ & & $33(24)$ \\
\hline & $\begin{array}{l}\text { Acute } \\
\text { pseudocysts }\end{array}$ & TM & 31 & NR & $23(74)$ & $2(9)$ & 9 & $6(19)$ \\
\hline & $\begin{array}{l}\text { Chronic } \\
\text { pseudocysts }\end{array}$ & TM & 64 & NR & $59(92)$ & $7(12)$ & 3 & $11(17)$ \\
\hline & Necrosis & TM & 43 & NR & $31(72)$ & $9(29)$ & 20 & $16(37)$ \\
\hline Smits et al. (1995) ${ }^{[6]}$ & Pseudocysts & TM & 37 & $34(92)$ & $24(65)$ & NR & NR & $6(16)$ \\
\hline \multirow{3}{*}{$\begin{array}{l}\text { Weckman et al. } \\
(2006)^{[11]}\end{array}$} & Pseudocysts & Total & 170 & NR & $165(86)$ & $8(4.8)$ & NR & $38(10)$ \\
\hline & & TP & 76 & NR & $69(91)$ & & & \\
\hline & & TM & 45 & NR & $41(91)$ & & & \\
\hline \multirow{4}{*}{$\begin{array}{l}\text { Cahen et al. } \\
(2005)^{[12]}\end{array}$} & Pseudocysts & Total & 92 & $89(97)$ & $65(71)$ & $18(20)$ & NR & $31(34)$ \\
\hline & & TP & & & $20(80)$ & & & \\
\hline & & TM & & & $36(67)$ & & & \\
\hline & & $\mathrm{TP}+\mathrm{TM}$ & & & $9(90)$ & & & \\
\hline \multirow{3}{*}{$\begin{array}{l}\text { Binmoeller et al. } \\
(1995)^{[13]}\end{array}$} & Pseudocysts & Total & 53 & $50(91)$ & $47(94)$ & $11(23)$ & NR & $4(11)$ \\
\hline & & TP & 33 & $33(100)$ & $31(94)$ & $5(16)$ & NR & $1(3)$ \\
\hline & & TM & 24 & $20(83)$ & $19(95)$ & $6(31)$ & NR & $3(12.5)$ \\
\hline \multirow[t]{3}{*}{ Sharma et al. (2002) $)^{[14]}$} & Pseudocysts & Total & 38 & $38(100)$ & $37(97)$ & $6(16.2)$ & NR & $5(13.1)$ \\
\hline & & TP & 5 & $5(100)$ & $5(100)$ & $1(20)$ & NR & 0 \\
\hline & & TM & 33 & $33(100)$ & $32(97)$ & $5(16)$ & NR & $5(15)$ \\
\hline $\begin{array}{l}\text { Beckingham et al. } \\
(1999)^{[15]}\end{array}$ & Pseudocysts & TM & 34 & $24(71)$ & $21(62)$ & $3(9)$ & NR & NR \\
\hline
\end{tabular}

TM: Non-EUS guided transmural drainage; TP: Transpapillary drainage; NR: Not reported

\begin{tabular}{|c|c|c|c|c|c|c|}
\hline Authors & Type of PFC & $\begin{array}{l}\text { No. of } \\
\text { patients }\end{array}$ & $\begin{array}{c}\text { Technical } \\
\text { success } n(\%)\end{array}$ & $\begin{array}{c}\text { Clinical } \\
\text { success } n(\%)\end{array}$ & $\begin{array}{c}\text { Recurrence } \\
n(\%)\end{array}$ & $\begin{array}{c}\text { Complications } \\
n(\%)\end{array}$ \\
\hline Ahn et al. $(2010)^{[16]}$ & Pseudocysts & 47 & $42(89)$ & $41(100)$ & $5(12)$ & $5(11)$ \\
\hline Lopes et al. $(2007)^{[17]}$ & $\begin{array}{l}\text { Pseudocysts, } \\
\text { Abscesses }\end{array}$ & 51 & $48(94.1)$ & NR & $11(17.7)$ & $2(3.2)$ \\
\hline Kruger et al. (2006) ${ }^{[18]}$ & $\begin{array}{l}\text { Pseudocysts, } \\
\text { Abscesses }\end{array}$ & 35 & $33(94)$ & $29(88)$ & $4(12)$ & $0(0)^{*}$ \\
\hline Antillon et al. $(2006)^{[19]}$ & $\begin{array}{l}\text { Chronic } \\
\text { pseudocysts }\end{array}$ & 33 & $31(94)$ & $27(82)$ & $1(3)$ & $5(15)$ \\
\hline \multirow{4}{*}{$\begin{array}{l}\text { Varadarajulu et al. } \\
(2008)^{[20]}\end{array}$} & Total & 60 & $57(95)$ & $53(93)$ & NR & $1(1.7)$ \\
\hline & Pseudocyst & 36 & & & & \\
\hline & Abscess & 15 & & & & \\
\hline & Necrosis & 9 & & & & \\
\hline \multirow[t]{6}{*}{ Hookey et al. $(2006)^{[3]}$} & Total & 116 & $108(93.1)$ & $102(87.9)$ & $19(16.4)$ & $13(11.2)$ \\
\hline & $\begin{array}{l}\text { Acute fluid } \\
\text { collections }\end{array}$ & 5 & $5(100)$ & $5(100)$ & $1(20)$ & $0(0)$ \\
\hline & Acute pseudocysts & 30 & $29(96.7)$ & $28(93.8)$ & $4(13.3)$ & $4(13.3)$ \\
\hline & $\begin{array}{l}\text { Chronic } \\
\text { pseudocysts }\end{array}$ & 64 & $61(95.3)$ & $59(92.2)$ & $12(18.8)$ & $7(10.9)$ \\
\hline & Pancreatic abscess & 9 & $9(100)$ & 8 (88.9) & $1(11.1)$ & $0(0)$ \\
\hline & Pancreatic necrosis & 8 & $4(50)$ & $2(25)$ & $1(12.5)$ & $2(25)$ \\
\hline
\end{tabular}

NR: Not reported. *: No procedure related complications occurred. However delayed complications were seen, such as stent blockage 4 (12\%), suboptimal drainage $3(9 \%)$ and infection of the cyst $4(12 \%)$ 
pancreas. This is very important as it can result in significant changes to the management plan. ${ }^{[5]}$ For instance, in one study involving 32 patients with pancreatic pseudocysts, performing EUS prior to fluid drainage led to the investigators altering the treatment plan for $37.5 \%$ of their patients. The reasons for this included resolution of the pseudocyst, appearance suspicious for cystic malignancy on EUS, unsatisfactory visualization of the cyst on EUS due to previous gastrectomy and not meeting the criteria for safe endoscopic drainage. ${ }^{[2]}$ In another study, 2 of the 53 patients diagnosed with pancreatic pseudocysts on prior imaging studies actually had pancreatic cyst neoplasms that were correctly diagnosed by EUS. ${ }^{[25]}$ A summary of the studies comparing the non-EUS and EUS-guided drainage of peripancreatic fluid collections is shown in Table 4.

\section{EUS-guided drainage versus surgery}

In a randomized trial comparing EUS-guided drainage of pseudocysts with surgical management, the technical success, clinical success, recurrence and complication rates were similar between these two groups. ${ }^{[26]}$ However up to 3 months, the quality of life, energy levels and physical function were significantly better for individuals who underwent EUS-guided drainage than those who had surgery. Also, EUS-guided drainage was significantly cheaper ( $\$ 8195$ for EUS-guided procedure and $\$ 22,475$ for surgery) and was associated with significantly shorter hospital admission duration than surgery (2 days for EUS-guided drainage and 6 days for surgery). Similar findings were reported in an earlier retrospective study by the same investigators. ${ }^{[27]}$ A summary of these studies is shown in Table 5.

\section{Controversies}

Transpapillary pancreatic duct stent placement The role of ductal stenting by ERCP in patients undergoing concomitant endoscopic transmural drainage is controversial. ${ }^{[3,28]}$ While pancreatic duct stent placement may not have a role in patients with disconnected duct syndrome (if the disruption is not bridged), its role in patients with partial disruptions that can be bridged remains to be established. In a study by Trevino et al., the clinical success rate was $97.5 \%$ in patients with pancreatic duct stents compared with $80 \%$ in the non-stent group. ${ }^{[28]}$ Although this difference was statistically significant, only a randomized trial will provide definite answers as to the advantages of bridging pancreatic duct stents in patients undergoing endoscopic transmural drainage.

\section{Disconnected duct syndrome}

In a recent randomized trial, the rate of recurrence of peripancreatic fluid collections was less in patients with permanent indwelling transmural stents compared to those patients in whom the stents were retrieved at endoscopy following peripancreatic fluid collection resolution. ${ }^{[29]}$ Although it appears logical that a permanent stent would decrease the rate of peripancreatic fluid collection recurrence, particularly in patients with disconnected duct syndrome by acting as a conduit for the disconnected gland to drain, the long-term consequences of a permanent foreign body within the peripancreatic fluid cavity is unclear. Hence, more studies that evaluate the rate of peripancreatic fluid collection recurrence and complications associated with this approach are needed.

\section{Conclusion}

The use of endoscopy with or without the aid of EUS can be a highly successful method for draining peripancreatic fluid collections. It appears to be not only technically and clinically effective, but also safer and less costly than surgical

\begin{tabular}{|c|c|c|c|c|c|c|}
\hline Authors & Procedure type & No. of patients & $\begin{array}{c}\text { Technical success } \\
n(\%)\end{array}$ & $\begin{array}{c}\text { Clinical success } \\
n(\%)\end{array}$ & $\begin{array}{l}\text { Hospital stay } \\
\text { (days) }\end{array}$ & $\begin{array}{c}\text { Complications } \\
n(\%)\end{array}$ \\
\hline \multirow{2}{*}{$\begin{array}{l}\text { Varadarajulu et al. } \\
(2008)^{[21]}\end{array}$} & Non-EUS & 15 & $5(33)$ & $13(87)$ & NR & $2(13.3)$ \\
\hline & EUS & 14 & $14(100)$ & $14(100)$ & $\mathrm{NR}$ & $0(0)$ \\
\hline \multirow[t]{2}{*}{ Park et al. (2009) $)^{[22]}$} & Non-EUS & 29 & $21(72)$ & $19(91)$ & NR & $3(10)$ \\
\hline & EUS & 31 & $29(94)$ & $28(97)$ & NR & $2(7)$ \\
\hline \multirow{2}{*}{$\begin{array}{l}\text { Varadarajulu et al. } \\
(2007)^{[25]}\end{array}$} & Non-EUS & 30 & & $27(90)$ & 2 & $1(3.3)$ \\
\hline & EUS & 23 & $21(100)$ & $20(95)$ & 2 & $0(0)$ \\
\hline
\end{tabular}

NR: Not reported

\begin{tabular}{|c|c|c|c|c|c|c|c|c|}
\hline Authors & $\begin{array}{l}\text { Procedure } \\
\text { type }\end{array}$ & $\begin{array}{c}\text { No. of } \\
\text { patients }\end{array}$ & $\begin{array}{c}\text { Technical } \\
\text { success } n(\%)\end{array}$ & $\begin{array}{c}\text { Clinical } \\
\text { success } n(\%)\end{array}$ & $\begin{array}{c}\text { Recurrence } \\
n(\%)\end{array}$ & Cost (\$) & $\begin{array}{l}\text { Hospital stay } \\
\text { (days) }\end{array}$ & $\begin{array}{c}\text { Complications } \\
n(\%)\end{array}$ \\
\hline \multirow{2}{*}{$\begin{array}{l}\text { Varadarajulu et al. } \\
(2010)^{[26]}\end{array}$} & EUS & 19 & 19 (100) & (94.4) & $0(0)$ & 8,195 & 2 & $0(0)$ \\
\hline & Surgery & 17 & 17 (100) & $\begin{array}{c}17(100) \\
P=1\end{array}$ & $\begin{array}{c}(5.8) \\
P=0.48\end{array}$ & $\begin{array}{c}22,475 \\
P<0.0001\end{array}$ & $\begin{array}{c}6 \\
P<0.0001\end{array}$ & $0(0)$ \\
\hline \multirow{3}{*}{$\begin{array}{l}\text { Varadarajulu et al. } \\
(2008)^{[27]}\end{array}$} & EUS & 20 & 20 (100) & $19(95)$ & $0(0)$ & 9,077 & 2.6 & $0(0)$ \\
\hline & Surgery & 10 & $10(100)$ & $10(100)$ & $1(10)$ & 14,815 & 6.5 & $0(0)$ \\
\hline & & & & $P=0.364$ & $P=0.13$ & $P=0.016$ & $P=0.008$ & \\
\hline
\end{tabular}


management. Therefore, endoscopic drainage of these fluid collections should be the method of choice, with surgical and percutaneous techniques being reserved for collections that are not amenable to endoscopic management. In pancreatic necrosis, the use of minimally invasive techniques was associated with lower complication rates than surgery and hence should be utilized in the appropriate setting.

\section{References}

1. Yusuf TE, Baron TH. Endoscopic transmural drainage of pancreatic pseudocysts: Results of a national and an international survey of ASGE members. Gastrointest Endosc 2006;63:223-7.

2. Bollen TL, van Santvoort HC, Besselink MG, van Leeuwen MS, Horvath KD, Freeny PC, et al. The Atlanta Classification of acute pancreatitis revisited. Br J Surg 2008;95:6-21.

3. Hookey LC, Debroux S, Delhaye M, Arvanitakis M, Le Moine O, Devière J. Endoscopic drainage of pancreatic-fluid collections in 116 patients: A comparison of etiologies, drainage techniques, and outcomes. Gastrointest Endosc 2006;63:635-43.

4. Jacobson BC, Baron TH, Adler DG, Davila RE, Egan J, Hirota WK, et al. ASGE guideline: The role of endoscopy in the diagnosis and the management of cystic lesions and inflammatory fluid collections of the pancreas. Gastrointest Endosc 2005;61:363-70.

5. Seewald S, Ang TL, Teng KC, Soehendra N. EUS-guided drainage of pancreatic pseudocysts, abscesses and infected necrosis. Digest Endosc 2009;21(Suppl. 1): S61-5.

6. Smits ME, Rauws EA, Tytgat GN, Huibregtse K. The efficacy of endoscopic treatment of pancreatic pseudocysts. Gastrointest Endosc 1995;42:202-7.

7. Munsell MA and Buscaglia JM. Acute pancreatitis. J Hosp Med 2010;5:241-50.

8. Varadarajulu S, Noone TC, Tutuian R, Hawes RH, Cotton PB. Predictors of outcome in pancreatic duct disruption managed by endoscopic transpapillary stent placement. Gastrointest Endosc 2005;61:568-75

9. Telford JJ, Farrell JJ, Saltzman JR, Shields SJ, Banks PA, Lichtenstein DR, et al. Pancreatic stent placement for duct disruption. Gastrointest Endosc 2002;56:18-24.

10. Baron TH, Harewood GC, Morgan DE, Yates MR. Outcome differences after endoscopic drainage of pancreatic necrosis, acute pancreatic pseudocysts, and chronic pancreatic pseudocysts. Gastrointest Endosc 2002;56:7-17.

11. Weckman L, Kylänpää ML, Puolakkainen P, Halttunen J. Endoscopic treatment of pancreatic pseudocysts. Surg Endosc 2006;20:603-7.

12. Cahen D, Rauws E, Fockens P, Weverling G, Huibregtse K, Bruno M. Endoscopic drainage of pancreatic pseudocysts: Long-term outcome and procedural factors associated with safe and successful treatment. Endoscopy 2005;37:977-83.

13. Binmoeller KF, Seifert H, Walter A, Soehendra N. Transpapillary and transmural drainage of pancreatic pseudocysts. Gastrointest Endosc 1995;42:219-24.
14. Sharma SS, Bhargawa N, Govil A. Endoscopic management of pancreatic pseudocyst: A long-term follow-up. Endoscopy 2002;34:203-7.

15. Beckingham IJ, Krige JE, Bornman PC, Terblanche J. Long term outcome of endoscopic drainage of pancreatic pseudocysts. Am J Gastroenterol 1999;94:71-4.

16. Ahn JY, Seo DW, Eum J, Song TJ, Moon SH, Park do H, et al. Single-step EUS-guided transmural drainage of pancreatic pseudocysts: Analysis of technical feasibility, efficacy, and safety. Gut Liver 2010;4:524-9.

17. Lopes CV, Pesenti C, Bories E, Caillol F, Giovannini M. Endoscopic-ultrasound-guided endoscopic transmural drainage of pancreatic pseudocysts and abscesses. Scand J Gastroentero 2007; 42: 524-9.

18. Kruger M, Schneider AS, Manns MP, Meier PN. Endoscopic management of pancreatic pseudocysts or abscesses after an EUS-guided 1-step procedure for initial access. Gastrointest Endosc 2006;63:409-16.

19. Antillon MR, Shah RJ, Stiegmann G, Chen YK. Single-step EUS-guided transmural drainage of simple and complicated pancreatic pseudocysts. Gastrointest Endosc 2006;63:797-803.

20. Varadarajulu S, Tamhane A, Blakely J. Graded dilation technique for EUS-guided drainage of peripancreatic fluid collections: An assessment of outcomes and complications and technical proficiency (with video). Gastrointest Endosc 2008;68:656-66.

21. Varadarajulu S, Christein JD, Tamhane A, Drelichman ER, Wilcox CM. Prospective randomized trial comparing EUS and EGD for transmural drainage of pancreatic pseudocysts (with videos). Gastrointest Endosc 2008;68:1102-11.

22. Park DH, Lee SS, Moon SH, Choi SY, Jung SW, Seo DW, et al. Endoscopic ultrasound-guided versus conventional transmural drainage for pancreatic pseudocysts: A prospective randomized trial. Endoscopy 2009;41:842-8.

23. Varadarajulu S. EUS followed by endoscopic pancreatic pseudocyst drainage or all-in-one procedure: A review of basic techniques (with video). Gastrointest Endosc 2009;69: S176-81.

24. Varadarajulu S, Wilcox CM, Tamhane A, Eloubeidi MA, Blakely J, Cannas CL. Role of EUS in drainage of peripancreatic fluid collections not amenable for endoscopic transmural drainage. Gastrointest Endosc 2007;66:1107-19.

25. Fockens P, Johnson TG, van Dullemen HM, Huibregtse K, Tytgat GN. Endosonographic imaging of pancreatic pseudocysts before endoscopic transmural drainage. Gastrointest Endosc 1997;46:412-6.

26. Varadarajulu S, Trevino j, Wilcox CM, Sutten B, christein JD. Randomized trial comparing EUS and surgery for pancreatic pseudocyst drainage. Gastrointest Endosc 2010;71:116.

27. Varadarajulu S, Lopes TL, Wilcox CM, Drelichman ER, Kilgore ML, Christein JD. EUS versus surgical cyst-gastrostomy for management of pancreatic pseudocysts. Gastrointest Endosc 2008;68:649-55.

28. Trevino JM, Tamhane A, Varadarajulu S. Successful stenting in ductal disruption favorably impacts treatment outcomes in patients undergoing transmural drainage of peripancreatic fluid collections. J Gastroen Hepatol 2010;25:526-31.

29. Arvanitakis M, Delhaye M, Bali MA, Matos C, De Maertelaer V, Le Moine O, et al. Pancreatic-fluid collections: A randomized controlled trial regarding stent removal after endoscopic transmural drainage. Gastrointest Endosc 2007;65:609-19.

How to cite this article: Varadarajulu S. Endoscopic management of pancreatic pseudocysts. J Dig Endosc 2012;3:58-64.

Source of Support: Nil, Conflict of Interest: None declared. 